\title{
PENAMBAHAN DAUN GEDI (Abelmoschus Manihot (L) Medik) SEBAGAI "ADDITIVE" DALAM AIR MINUM DAN PENGARUHNYA TERHADAP PERFORMANS AYAM KAMPUNG SUPER
}

\author{
Desben Kogoya, J. S. Mandey*, L. J. Rumokoy, M.N. Regar \\ Fakultas Peternakan, Universitas Sam Ratulangi, Manado 95115
}

\begin{abstract}
ABSTRAK
Penelitian ini bertujuan untuk mengetahui performans ayam kampung yang diberi juice daungedi(Abelmoschus manihot (L) Medik) dalam air minum.Penelitian dilakukan dengan menggunakan ayam kampungsuper umur 1 hari sebanyak 100 ekor. Juice daun gedi yang diberikan terdiri dari perlakuan: $\mathrm{P} 0=$ air minum tanpa daun gedi; $\mathrm{P} 1=10 \mathrm{ml}$ juice daun gedi (JDG)/liter air minum, P2 $=20 \mathrm{ml}$ JDG/liter air minum dan P3 $=30 \mathrm{ml}$ JDG/liter air minum. Perlakuan mulai diberikan pada ayam umur 6 minggu, dan pengambilan data dilakukan selama 5 minggu.Pakan yang diberikan adalah pakan komersial $73 \%$ ditambah jagung $10 \%$ dan dedak halus $17 \%$ dengan komposisi: protein kasar 19,49\%, serat kasar 4,66\%, lemak 3,63\%, Ca 1,02\%, P $0,66 \%$, dan energi metabolis 2920 $\mathrm{Kkl} / \mathrm{kg}$, yang diberikan ad libitum. Penelitian ini menggunakan Rancangan Acak lengkap (RAL) pola 1 arah yang terdiri dari 4 perlakuan dan 5 ulangan. Variabel yang diukur adalah konsumsi pakan, konsumsi air minum, pertambahan berat badan, dan konversi pakan.Hasil penelitianmenunjukkan bahwa pemberian juice daun gedi dalam air minum sampai $30 \mathrm{ml} / \mathrm{L}$ air minum memberikan pengaruh berbeda tidak
\end{abstract}

*Korespondensi (corresponding author): Email: jetsm_fapet@yahoo.co.id nyata terhadap konsumsi pakan dan konsumsi air minum, dan memberikan pengaruh berbeda sangat nyata terhadap pertambahan berat badan dan konversi pakan. Antara perlakuan $10 \mathrm{ml} / \mathrm{L}$ air minum (P1) dan $20 \mathrm{ml} / \mathrm{L}$ air minum (P2) memberikan pengaruh yang tidak berbeda nyata terhadap pertambahan berat badan, tetapi perlakuan ini sangat nyata meningkat dibanding dengan perlakuan kontrol, tanpa daun gedi. Nilai tertinggi konversi pakan diperoleh pada perlakuan P3 dan nilai terendah diperoleh pada perlakuan P1. Artinya nilai konversi pakan terbaik adalah pada perlakuan P1. Berdasarkan hasil penelitian ini dapat disimpulkan bahwa juice daun gedi dapat digunakan sebagai salah satu alternatif aditif dalam air minum ayam kampung sampai $20 \mathrm{ml} / \mathrm{L}$ dilihat dari nilai pertambahan berat badan dan konversi pakan.

Kata kunci: Ayam kampung, Air minum, Feed Additive, Daun Gedi.

\section{ABSTRACT}

UTILIZATION OF "GEDI LEAF (Abelmoschus Manihot (L) Medik) AS“ADDITIVE" IN DRINKING WATER RELATED TO THE PERFORMANCE OF INDONESIAN SUPER NATIVE CHICKEN.

Research was done to evaluate the performance of Indonesian super native chicken treated with "Gedi" leaf (Abelmoschus Manihot (L) Medik) as 
"Additive" in drinking water. Study was conducted using hundred individuals of the Indonesian super native day old chicken. The juice of "Gedi" leaf (Abelmoschus Manihot (L) Medik) was given as in forms of the four treatments as follows, drinking water without "Gedi" leaf as control (P0), drinking water with $10 \mathrm{ml}$ juice of "Gedi" leaf per liter of drinking water (P1), drinking water with $20 \mathrm{ml}$ juice of "Gedi" leaf per liter of drinking water (P2), and drinking water with $30 \mathrm{ml}$ juice of "Gedi" leaf per liter of drinking water (P3). Treatments were applied to the birds at 6 weeks old by completely randomized design five replications at each treatment. Data were taken during 5 weeks. Feeds were using 73 percents of commercial feed added by 10 percents of corn and 17 percents of rice bran with nutritional composition of crude protein 19.49 percents, crude fiber 4.66 percents, fat 3.63 percents, Calcium 1.02 percents, Phosphorus 0.66 percents and metabolic energy of $2920 \mathrm{kcal} / \mathrm{kg}$, all given ad libitum. Variables measurement were focused on feed consumption, drinking water consumption, average daily gain, and feed conversion. Results showed that drinking water with $30 \mathrm{ml}$ juice of "Gedi" leaf per liter of drinking water (P3) was not significantly different with other treatments for feed and drinking water consumption, except for average daily gain and feed conversion. The treatments of P1 and P2 were not significantly different for average daily gain, but these treatments were higher in average daily gain compared with control (P0). The highest value of feed conversion was obtained at treatment P3 and the lowest value was found at treatment $\mathrm{P} 1$. These values indicated that the best feed conversion was treatment P1. Therefore, it can be concluded that juice of "Gedi" leaf can be used as the alternative additive feed in drinking water up to $20 \mathrm{ml}$ juice of "Gedi" leaf per liter of drinking water in term of high average daily gain and feed conversion of Indonesian super native chicken.

Key words: Drinking water, "Gedi" leaf, Indonesian super native chicken.

\section{PENDAHULUAN}

Pemberian imbuhan pakan (feed additive) sangat penting untuk meningkatkan kesehatan dan produktivitas ternak unggas.Imbuhan pakan yang umum digunakan selama ini sebagai pemacu pertumbuhan (growth promoter) adalah antibiotik.Namun penggunaan antibiotik sebagai pemacu pertumbuhan ternak unggas semakin ditinggalkan karena adanya larangan penggunaan antibiotik oleh Uni Eropa pada tahun 1998.Hal ini karena isu menyangkut residu antibiotik dalam pakan yang menimbulkan masalah kesehatan konsumen.

Para ahli nutrisi ternak sekarang tertarik untuk mengevaluasi potensi alamiah seperti herbal dan ekstrak tanaman yang telah banyak digunakan untuk bermacam-macam tujuan dalam 
diet manusia.Pemacu pertumbuhan natural yang berasal dari herbal dapat digunakan sebagai pengganti antibiotik sintetik jika digunakan dalam level optimal (Banerjee, et al., 2013).Odomelam, et al. (2013) menyatakan bahwa herbal, rempahrempah dan derivat tanaman telah digunakan dalam pakan ternak sebagai feed additive yang disebut sebagai "phytogenic feed additives". Kebanyakan tanaman herbal adalah aman dan ekonomis, dan umumnya ekstrak tanaman tidak memiliki masalah "drug resistance".

Daun gedi (Abelmoschus manihot (L) Medik)adalah salah satu jenis tanaman yang dikategorikan dalam kelompok tanaman obat/tanaman herbal.Tanaman ini memiliki potensi anti-inflamatori, antibakteri, antiviral, antioksidan, serta dapat mengeliminasi radikal bebas.

Tanaman gedi asal Sulawesi Utara dan manfaat daun gedi terhadap ayam pedaging telah diteliti oleh Mandey, et al. (2013); Mandey, et al. (2014); dan Mandey, et al. (2015). Hasil penelitian mendapatkan bahwa tanaman gedi asal Sulawesi Utara yang ternyata memiliki beberapa ciri morfologi diidentifikasi sebagai species
(Abelmoschus manihot

Medik).Penggunaan juice daun gedi dalam pakan ayam pedaging ternyata menurunkan konsumsi pakan dan pertambahan berat badan. Tetapi konversi pakan dan persentase karkas ada dalam kategori baik serta persentase lemak abdominal sangat nyata menurun. Dari penelitian ini diperoleh daging ayam untuk tujuan tertentu, yaitu sebagai pangan fungsional yang rendah lemak, aman dan sehat, dan hal ini disebabkan karena juice daun gedi mengandung senyawa bioaktif yang memiliki potensi anti-oksidan, anti-mikroba, hepatoprotektif, sebagai pemacu pertumbuhan. Namun dari segi komersial belum optimal menghasilkan daging ayam dengan berat pasar. Hal ini terjadi karena daun gedi mengandung musilase yang tinggi. Hasil penelitian selanjutnya terhadap daun gedi dalam bentuk juice daun gedi yang diberikan melalui air minum pada ayam pedaging mendapatkan hasil berat badan yang lebih tinggi dibanding ketika diberikan melalui ransum (Mandey dan Pontoh, 2016).

Senyawa flavonoid sudah diisolasi dari juice daun gedi dan dilaporkan memiliki aktivitas antioksidan dengan nilai IC50 dari 
727,53 $\mu \mathrm{g} / \mathrm{mL}$ (Taroreh, et al., 2016). Selanjutnya Chumbhale,et al. (2016) menyatakan bahwa batang tanaman gedi telah diteliti mengandung senyawa bioaktif yang bertanggung jawab untuk aktivitas antioksidan.

Keberhasilan budidaya ayam kampung secara intensif memerlukan ketersediaan sumber ransum yang berkualitas dan berkesinambungan. Untuk itu penggunaan bahan pakan alternatif sangat dibutuhkan agar kebutuhan nutrisi ternak dapat terpenuhi dengan harga yang terjangkau. Budidaya ayam kampung di Indonesiaumumnya menggunakan pakan ayam broiler padahal kebutuhan nutrisi ayam kampung lebih rendah dibandingkan dengan kebutuhan nutrisi ayam broiler (Fitasari, dkk., 2013).Hasil penelitian Astuti (2012) bahwa penggunaan ransum berbasis konsentrat broiler $75 \%$ memberikan kinerja yang terbaik yaitu konsumsi pakan yang lebih rendah, pertambahan berat badan yang lebih tinggi dan konversi pakan yang lebih rendah.

Penelitian pemanfaatan daun gedi pada ayam kampung super belum pernah dilakukan, karena itu penelitian ini bertujuan untuk mengetahui performans ayam kampung yang diberi juice daun gedi(Abelmoschus manihot (L) Medik) dalam air minum.

\section{MATERI DAN METODE}

Penelitian menggunakan ayam kampungsuper umur 1 hari sebanyak 100 ekor. Juice daun gedi yang diberikan terdiri dari perlakuan: $\mathrm{P} 0=$ air minum tanpa daun gedi; $\mathrm{P} 1=10 \mathrm{ml}$ juice daun gedi (JDG)/liter air minum, P2 =20 ml JDG/liter air minum dan P3 =30 ml JDG/liter air minum. Perlakuan mulai diberikan pada ayam umur 5 minggu.Pakan yang diberikan adalah pakan komersial ditambah jagung dan dedak halus dengan komposisi: protein kasar 19,49\%, serat kasar 4,66\%, lemak $3,63 \%$, Ca $1,02 \%$, P 0,66\%, dan energi metabolis $2920 \mathrm{Kkl} / \mathrm{kg}$, yang diberikan ad libitum. Komposisi dan kandungan zat-zat makanan bahan pakan dapat dilihat pada Tabel 1 dan komposisi dan kandungan zat-zat makanan ransum percobaan dapat dilihat pada Tabel 2 . Penelitian ini menggunakan rancangan acak lengkap (RAL) pola 1 arah yang terdiri dari 4 perlakuan dan 5 ulangan. Variabel yang diukur adalah konsumsi pakan, konsumsi air minum, pertambahan berat badan, dan konversi pakan. 
Tabel 1. Komposisi dan Kandungan Zat-zat Makanan Bahan Pakan

\begin{tabular}{lcccc}
\hline \multicolumn{1}{c}{ Zat-zat Makanan } & $\begin{array}{c}\text { Pakan } \\
\text { Komersial }^{*}\end{array}$ & $\begin{array}{c}\text { Tepung Daun } \\
\text { Gedi* }\end{array}$ & Jagung $^{* *}$ & Dedak Halus $^{* *}$ \\
\hline Bahan Kering (\%) & 93,38 & 81,72 & & \\
Protein Kasar (\%) & 22,34 & 20,18 & 9,42 & 13,44 \\
Serat Kasar (\%) & 4,66 & 17,53 & 2,15 & 6,35 \\
Lemak (\%) & 3,15 & 1,06 & 5,17 & 6,07 \\
Beta-N (\%) & 57,26 & 31,17 & & \\
Ca (\%) & 1,28 & 3,29 & 0,22 & 0,19 \\
P (\%) & 0,71 & 0,39 & 0,6 & 0,73 \\
Metionin (mg/g) & 17 & 16 & & \\
Lisin (mg/g) & 47 & 425 & & 2695 \\
GE (Kkal/kg) & 3685 & 3419 & & \\
ME (Kkal/kg) & & & 3182 & \\
\hline
\end{tabular}

Keterangan: * = Mandey (2013); ** Dengah (2016)

Tabel 2. Komposisi dan Kandungan Zat-zat Makanan Ransum Percobaan

\begin{tabular}{lc}
\hline Komposisi Ransum Percobaan: & Jumlah \\
\hline Ransum Komersial (\%) & 73 \\
Jagung (\%) & 10 \\
Dedak Halus (\%) & 17 \\
\hline Total & 100 \\
\hline & \\
Komposisi Zat-zat Makanan Ransum Percobaan: & 19,49 \\
\hline Protein Kasar (\%) & 3,63 \\
Lemak (\%) & 4,66 \\
Serat Kasar(\%) & 1,02 \\
Ca (\%) & 0,66 \\
P (\%) & 2920 \\
ME (Kkal/kg) & \\
\hline
\end{tabular}

\section{HASIL DAN PEMBAHASAN}

Data hasil penelitian penggunaan

juice daun gedi dalam air minum dan pengaruhnya terhadap performans ayam kampung disajikan pada Tabel 3. 
Tabel 3. Pengaruh Penambahan Juice Daun Gedi Dalam Air Minum Terhadap Performans Ayam Kampung

\begin{tabular}{|c|c|c|c|c|c|}
\hline \multirow{2}{*}{ Parameter } & \multicolumn{4}{|c|}{ Perlakuan } & \multirow{2}{*}{$p$ Value } \\
\hline & P0 & P1 & P2 & P3 & \\
\hline $\begin{array}{l}\text { Konsumsi Pakan } \\
\text { (g/ekor) }\end{array}$ & 2252,04 & 2237,52 & 2254,24 & 2248,48 & .856 \\
\hline $\begin{array}{l}\text { Konsumsi Air Minum } \\
\text { (ml/ekor) }\end{array}$ & 4918,80 & 4892,80 & 4936,20 & 4856,80 & .917 \\
\hline $\begin{array}{l}\text { Pertambahan Berat } \\
\text { Badan (g/ekor) }\end{array}$ & $735,31^{\mathrm{b}}$ & $779,36^{\mathrm{a}}$ & $774,62^{a}$ & $682,00^{\mathrm{c}}$ & .000 \\
\hline Konversi Pakan & $3,06^{\mathrm{c}}$ & $2,87^{\mathrm{a}}$ & $2,91^{\mathrm{b}}$ & $3,30^{\mathrm{d}}$ & .000 \\
\hline
\end{tabular}

Keterangan: Superskrip yang berbeda pada baris yang sama menunjukkan adanya perbedaan yang nyata $(\mathrm{P}<0,05)$

\section{Pengaruh Perlakuan Terhadap}

\section{Konsumsi Pakan}

Konsumsi pakan ayam kampung selama penelitian berkisar antara 2237,52 - 2254,24 g/ekor. Konsumsi pakan hasil penelitian ini masih ada dalam kisaran konsumsi ayam lokal di Jimmy's Farm yang dilaporkan Fahrudin (2016) yaitu 1261,81 - 2255,88 g/ekor.

Hasil analisis keragaman pemberian juice daun gedi dalam air minum sampai $30 \mathrm{ml} / \mathrm{L}$ air minum memberikan pengaruh tidak berbeda nyata $(\mathrm{P}>0,05)$ terhadap konsumsi pakan. Hal ini berarti pemberian juice daun gedi sampai 30 $\mathrm{ml} / \mathrm{L}$ air minum belum mengganggu selera makan dari ayam.

Fitobiotik dikenal dengan efek farmakologinya dan umum digunakan dalam pengobatan tradisional dan alternatif pada manusia. Lebih jauh, fitobiotik pada manusia berperan penting sebagai penambah selera dan bahan pengawet. Peran fitobiotik disebabkan oleh unsur-unsur primer dan sekunder. Sejumlah besar studi in vitro dan in vivo mengkonfirmasi aktivitas yang luas dari fitobiotik terhadap nutrisi ternak, seperti merangsang konsumsi pakan, antimikroba, coccidiostatis, anthelmintic dan immunostimulating (Panda,et al.,2006).

Hasil penelitian ini tidak sama dengan yang dilaporkan Alabi, et al. (2017)bahwa penggunaan ekstrak aqua daun kelor (Moringaoleifera L.) sampai $90 \mathrm{ml} / \mathrm{L}$ air minum menurunkan konsumsi pakan hingga12,83\%, dan penelitian Windisch, et al. (2008) yang menyatakan bahwa air minum yang mengandung $15 \mathrm{ml} / \mathrm{L}$ gel tanaman lidah buaya (Aloe vera) meningkatkan konsumsi pakan karena substansi fitogenik dalam tanaman ini yang 
mungkin merangsang sekresi endogen dan memperbaiki pertumbuhan ayam.

\section{Pengaruh Perlakuan Terhadap Konsumsi Air Minum}

Konsumsi air minum ayam kampung selama penelitian berkisar antara 4856,80 - 4936,20 ml/ekor.Hasil analisis keragaman pemberian juice daun gedi dalam air minum sampai 30 $\mathrm{ml} / \mathrm{L}$ memberikan pengaruh tidak berbeda nyata $(\mathrm{P}>0,05)$ terhadap konsumsi air minum. Hal ini menunjukkan bahwa juice daun gedi tidak mempengaruhi konsumsi air minum dan indera perasa. Scott, et al. (1982) mengatakan, banyak faktor yang dapat meningkatkan dan menurunkan konsumsi air minum, antara lain: bau, rasa, aroma dan additive yang digunakan.

Hasil penelitian ini tidak sama dengan yang dilaporkan Durrani, et al. (2008), bahwa konsumsi pakan dan konsumsi air minum menurun nyata ketika ditambahkan tepung daun Mimba dalam air minum ayam.

\section{Pengaruh Perlakuan Terhadap Pertambahan Berat Badan}

Pertambahan berat badan ayam kampung dalam penelitian ini berkisar antara 682,00 - 779,36 g. Pertambahan berat badan hasil penelitian ini masih ada dalam kisaran pertambahan berat badan ayam lokal di Jimmy's Farm yang dilaporkan Fahrudin (2016) yaitu 611,88 - 1020 g/ekor. Menurut Candrawati (1999) bahwa ayam kampung yang diberikan ransum dengan kandungan energy $3100 \mathrm{Kkal} / \mathrm{kg}$ dan protein kasar $22 \%$ berat badannya selama 8 minggu adalah 542g/ekor atau 9,67g/ekor/hari sedangkan yang mendapat ransum dengan energy $2823 \mathrm{Kkal} / \mathrm{kg}$ dan protein kasar15,33\% adalah 391g/ekor.

Hasil analisis keragaman pemberian juice daun gedi dalam air minum sampai $30 \mathrm{ml} / \mathrm{L}$ memberikan pengaruh berbeda sangat nyata $(\mathrm{P}<0,01)$ terhadap pertambahan berat badan. Antar perlakuan $10 \mathrm{ml} / \mathrm{L}$ air minum (P1) dan $20 \mathrm{ml} / \mathrm{L}$ air minum (P2) memberikan pengaruh yang tidak berbeda nyata terhadap pertambahan berat badan, tetapi perlakuan ini sangat nyata meningkat dibanding dengan perlakuan control, tanpa daun gedi. Pertambahan berat badan pada perlakuan $30 \mathrm{ml} \mathrm{JDG} / \mathrm{L}$ air minum (P3) sangat menurun dibanding dengan perlakuan P1 dan P2. Semakin meningkatnya pertambahan berat badan sampai pada perlakuan P2 mungkin 
disebabkan oleh adanya senyawasenyawa kimia farmakologi, seperti karbohidrat, saponin, steroid, flavonoid dan alkaloid yang ada dalam juice daun gedi, seperti yang dilaporkan oleh Mandey, dkk. (2015) a . Mandey, dkk. $(2015)^{\mathrm{a}}$ melaporkan bahwa kandungan total flavonoid setara kuersetin daun gedi adalah $0,48 \%$ b/b. Penelitian ini sejalan dengan yang dilaporkan oleh Durranietal(2008), yang mendapatkan adanya perbaikan dalam berat badan ketika diberikan tepung daun Mimba dalam air minum $50 \mathrm{ml} / \mathrm{L}$.

Tanaman (fitogenik) pemacu pertumbuhan berperan utama sebagai regulator flora intestinal menekan pertumbuhan patogen potensial dalam saluran pencernaan, terutama dalam stress periode kritis (Windisch, et al., 2008; Brenes and Roura, 2010). Pada ayam periode kritis terutama permulaan pemberian pakan, bakteri patogen dapat berakibat pada penurunan pertumbuhan dan kematian ternak (Jang, et al., 2007). Semakin meningkatnya jumlah juice daun gedi dalam air minum menekan pertumbuhan bakteri patogen, sehingga pertambahan berat badan ayam semakin meningkat.

\section{Pengaruh Perlakuan Terhadap}

\section{Konversi Pakan}

Nilai konversi diperoleh dari jumlah pakan dikonsumsi dibagi dengan pertambahan bobot badan. Rataan nilai konversi dapat dilihat pada Tabel 3, berkisar antara 2,87 - 3,30.Konversi pakan hasil penelitian ini masih ada dalam kisaran konversi pakan ayam lokal di Jimmy's Farm yang dilaporkan Fahrudin (2016) yaitu 1,79-3,42. Nilai tertinggi diperoleh pada perlakuan P3 dan nilai terendah diperoleh pada perlakuan P1. Artinya nilai konversi pakan terbaik adalah pada perlakuan P1. Hasil analisis keragaman terhadap konversi pakan antar perlakuan menunjukkan adanya perbedaan yang sangat nyata $(\mathrm{P}<0.01)$.

Hasil penelitian ini sejalan dengan yang dilaporkan Islam et al. (2017) yang melaporkan bahwa penggunaan tanaman lidah buaya sampai $15 \% / \mathrm{L}$ air minum mendapatkan pertambahan berat badan dan efisiensi pakan berbeda nyata $(\mathrm{P}<0,05)$ dibanding dengan air minum tanpa ekstrak lidah buaya sedangkan konsumsi pakan dan air minum tidak berbeda nyata.

Antioksidan natural pada tanaman obat dapat menghambat pengaruh negatif dari stress lingkungan dan dapat meningkatkan fungsi kekebalan melawan berbagai tipe 
penyakit dan akibatnya terjadi peningkatan performans dari ayam (Botsoglouetal.,2001). Sejalan dengan hasil penelitian ini, Guo, et al. (2004) mendapatkan efisiensi pakan yang lebih tinggi pada ayam broiler yang diberi herbal Chinese pada hari ke 21-28.Ratarata pertambahan berat badan dan konversi pakan ayam meningkat pada perlakuan ekstrak daun AOLE $10 \mathrm{ml} / \mathrm{L}$ (Jabri,et al., 2017).Penggunaan ekstrak aqua daun kelor (Moringaoleifera L.) sampai $90 \mathrm{ml} / \mathrm{L}$ air minum memperbaiki konversi pakan 9,11\% (Alabi, et al., 2017).Sebaliknya, pemberian ekstrak daun pepaya sampai $25 \mathrm{ml} / \mathrm{L}$ air minum tidak berpengaruh terhadap konsumsi air minum, konsumsi pakan, PBB dan konversi pakan (Sudjatinah, dkk., 2005).

Konversi pakan yang lebih baik yang diteliti pada ayam yang diberi ekstrak daun memberi kesan bahwa ekstrak daun meningkatkan kemampuan ternak menggunakan zat-zat yang tersedia dalam pakan dan ekstrak.

\section{KESIMPULAN}

Berdasarkan hasil penelitian ini dapat disimpulkan bahwa juice daun gedi dapat digunakan sebagai salah satu alternatif aditif dalam air minum ayam kampussng sampai $20 \mathrm{ml} / \mathrm{L}$ dilihat dari nilai pertambahan berat badan dan konversi pakan.

\section{DAFTAR PUSTAKA}

Alabi, O.J., A.D. Malik, J.W. Ng'ambi, P. Obaje P and B.K. Ojo. 2017. Effect of Aqueous Moringa Oleifera (Lam) Leaf Extracts on Growth Performance and Carcass Characteristics of Hubbard Broiler Chicken. Brazilian Journal of Poultry Science. 19 (2): 273-280.

Astuti, N. 2012. Kinerja ayam kampung dengan ransum berbasis konsentrat broiler. Journal Agri Sains 4 (5): 51-58.

Banerjee, S., S.K. Mukhopadhayay, S.Ganguly. 2013. Phytogenic growth promoter as replacers for antibiotic growth promoter in poultry birds. Journal. Anim. Genet. Res. 1(1): 6-7.

Botsoglou,N.A. and D. J. Fletouris. 2001. Drug Residuesin Foods: Pharmacology, Food Safety and Analysis. Marcel Dekker, Inc. Publ., New York, USA.

BrenesA,E. Roura.2010. Essential oils in poultry nutrition:main effects and modes of action. .Anim.Feed Sci.Technol.158:1-14.

Candrawati,D.P.M.A.1999.Pendugaan Kebutuhan Energi dan Protein Ayam Kampung Umur 0-8 minggu.Tesis.Institut Pertanian Bogor.

Chumbhale D. S., M. J. Chavan, S.R. Chaudhari and C.D. 
Upasani.2016. Free radical scavenging and anti-lipid peroxidation activity of (Abelmoschus manihot (L) Medik) Stems. Research Communication. The Explorer 1(1): 86-91

Dengah, S. P. 2016. Pengaruh Penggantian Tepung Ikan dengan Tepung Maggot (Hermetia illucens) Dalam Ransum Terhadap Performans Broiler. Skripsi. Fakultas Peternakan, Universitas Sam Ratulangi. Manado.

Durrani,F.R., A. Sultan, M. Jan, N. Chand, and Z. Durrani. 2008. Immunomodulatory and growth promoting effects of Neem (Azadirachta indica) leaves in fusion in broiler chicks. Sarhad J.of Agric 24 (5):234-238

Fahrudin, A., W. Tanwiriah, H. Indrijani. 2016. Konsumsi Ransum, Pertambahan Bobot Badan Dan Konversi Ransum Ayam Lokal Di Jimmy's Farm Cipanas Kabupaten Cianjur. Skripsi. Universitas Padjadjaran.

Fitasari, E., K. Reo, dan N. Niswi. 2013. Penggunaan kadar protein berbeda pada ayam kampung terhadappenampilan produksi dan kecernaan protein. Jurnal Ilmu-Ilmu Peternakan 26 (2): 73 -83 .

Guo,F.C., R.P.Kwakkel, J.Soede, B.A. Williams and M.W.A.Verstegen. 2004. Effect of a Chinese herb medicine formulation, as an alternative for antibiotics, on performance of broilers.Br. Poult. Sci., 45:793-797.
Islam, Md. M., Md. M. Rahman, S. Sultana, Md. Z. Hassan, Abd.G. Miahand Md. Abd.Hamid. 2017. Effects of aloevera extract in drinking water on broiler performance. Asian J. Med.Biol. Res. 3 (1), 120-126.

Jang,I, S.,Y.H. Ko, S.Y. Kang, and C.Y. Lee. 2007.Effect of a commercial essential oil on growth performance, digestive enzyme activity and intestinal microflora population in broiler chickens. Anim .Feed Sci.Tech. 134:304-15.

Mandey, J. S. 2013. Daun Gedi (Abelmoschus manihot $(\mathrm{L})$ Medik) Asal Sulawesi Utara Sebagai Sumber Bahan Pakan Ayam Pedaging. Disertasi. Program Pascasarjana, Universitas Brawijaya. Malang.

Mandey, J.S., Soetanto H., Sjofjan O., and Tulung B. 2013. The effects of native gedi leaves (Abelmoschus manihot (L) Medik.) of Northern SulawesiIndonesia as a source of feedstuff on the performance of broilers. Int. Journal. of Biosciences 3(10):82-91.

Mandey, J.S., H. Soetanto., O. Sjofjan., B. Tulung. 2014. Genetic characterization, nutritional and phytochemicals potential of gedi leaves (Abelmoschus manihot (L) Medik) growing in the North Sulawesi of Indonesia as a candidate of poultry feed. J. of Res. in Biol. 4 ( 2): 68-73

Mandey, J.S., F.N. Sompie., Rustandi., C.J. Pontoh. 2015 a . Effects of 
gedi leaves (Abelmoschus manihot (L) Medik) as a herbal plant rich in mucilages on blood lipid profiles and carcass quality of broiler chickens as functional food. Procedia Food Sci. 3: 132136.

Mandey, J.S., H. Soetanto, O. Sjofjan, B. Tulung. $2015^{\mathrm{b}}$. Digestibility and nutritional value of gedi (Abelmoschus manihot (L) Medik) leaves meal in the diet of broilers. Proceeding Part I. The 6th International Seminar on Tropical Animal Production (ISTAP). Yogyakarta, 20-22 October, 2015.

Mandey, J.S. dan C.J. Pontoh.2016. Efek Ekstrak Aqua dan Juice Daun Gedi (Abelmoschus manihot (L) Medik) dalam Air Minum Sebagai "Growth Promoter" Pada Ayam Pedaging. Laporan Penelitian RUU-Unsrat, 2016.

Odoemelam, V.U., I.F. Etuk, Ndelekwute, T.C. Iwuji and C.C. Ekwe. 2013. Herbs and Spices: Options for Sustainable Animal Production. Journal of Biology, Agriculture and Health care. 3(7): 116-123.
PandaK.,RamaRaoS.V.,RajuM.V.L.N.,2 006. Natural growth promoters have potential in poultry feeding systems.Feed Tech.10(8),23-25

Scott, M.L., M.C. Nesheim, and R.J. Young. 1982. Nutrition of the Chicken. $3^{\text {rd }}$ Ed. M.L. Scott \& Assoc. Ithaca, New York.

Steel, R.G.D. and J.A. Torrie. 1982. Principles and Procedures of Statistics. $2^{\text {nd }}$ Ed. McgrawHill, Book Co, Inc. New York, Toronto, London.

Sudjatinah, C.H. Wibowo dan P. Widiyaningrum. 2005. Pengaruh pemberian ekstrak daun papaya terhadap tampilan produksi ayam broiler. J. Indonesian Tropical Animal Agriculture. 30(4)

Taroreh, M.I.R., A. Widiyantoro, A. Murdiati, P. Hastuti, and S. Raharjo. 2016. Identification of flavonoid from leaves of gedi (Abelmoschus manihot (L) and its antioxidant activity. AIP Conference Proceeding, p 1-6.

Windisch,W.,K. Schedle,C. Plitzner and A. Krois-mayr.2008.Use of phytogenic products as feed additives for swine and poultry. .J. Anim. Sci., 86:140-148. 